\title{
LINGUISTIC SCIENCE AND ITS CLASSROOM REFLECTIONS
}

\author{
Mary Jane M. Norris \\ University of Michigan
}

This paper is an attempt to bring together the various assumptions, statements, findings, or other contributions generally included within the scope of linguistic science that have a bearing on language teaching, and to show to some extent how they are reflected in the language classroom. These elements of linguistic science can be divided into the following five points:

1. The realization of the nature of language.

a. Language is vocal.

b. Language symbols are arbitrary.

c. Language has system.

d. Language is for communication.

e. Language is made up of habits.

f. There is a relation between a language and the culture in which it is used.

g. Languages change.

h. No two languages have the same set of patterns of pronunciation, words, and syntax. ${ }^{1}$

2. The realization (assumption) that patterns of one's native language interfere with learning later the patterns of another language.

3. Methods of analyzing and describing languages.

4. Descriptions of some languages.

5. Techniques for comparison of two languages.

These points with their reflections, or potential reflections, in the classroom follow.

1Redundancy might be added as a feature of language, a concept which has come to the fore through the work of Claude L. Shannon and W. Weaver, The Mathematical Theory of Communication, Urbana: University of Illinois Press, 1949. Waldo E. Sweet in "The Carrot on the Stick," editorial, Language Leaming, 9.1-2, 1959, mentions a use of redundancy, as fill-the-space exercises, in the language classroom. 


\section{THE REALIZATION OF THE NATURE OF LANGUAGE}

a. Language is vocal.

The vocal nature of language makes us view the written language as secondary. It brings the primary attention upon oral-aural work in the classroom. Henry Sweet in The practical Study of Languages, 1899, advocated beginning with the spoken language. Leonard Bloomfield in An Introduction to the Study of Language, 1914, p. 293, said that "not one in a thousand [foreign language students in the USA] ever learns to carry on a conversation in the foreign language," and he stressed, among other things, pronunciation drill. The same emphasis is made by Harold E. Palmer in The Oral Method of Teaching Languages, 1923. Charles C. Fries in Teaching and Learning English as a Foreign Language, 1945, presents the "oral approach," with the aim of learning to speak a language and to understand it when it is spoken--this does not mean, he points out, that reading and writing cannot be used, but that reading and writing are not the aim of the first stage of learning a language. The English Language Institute of the University of Michigan follows the oral approach in its Intensive Course in English, which began in 1941. From 1942 to 1945, the Intensive Language Program of the American Council of Learned Societies (ACLS) got underway to teach the spoken language. Linguists conducted the classes, using speakers of the language as informants and models. In the classes, mimicry and memorization (known as Mim-Mem) played a great part. In 1943-44 the Army Specialized Training Program (ASTP) at various American universities also emphasized the spoken language and followed techniques of the ACLS program. These techniques are stated later by William E. Welmers in Spoken English as a Foreign Language, 1953, Instructor's Manual, ACLS Program in English as a Foreign Language.

b. Language symbols are arbitrary.

There are no true or correct symbols or sets of symbols except with reference to the language and dialect of which they are a part. What "lift" is a symbol for in London is symbolized by "elevator" in Ann Arbor and by "ascensor" in Buenos Aires. No one of these is a truer symbol of the object than any of the others. This arbitrariness of language symbols is significant in deciding upon the dialect to be taught--it is not a matter of one dialect being more correct than another, but a matter of which dialect the student will encounter most or have most use for. The basis for dialect decision is brought out by 
Fries (1945, p. 4), and also by David W. Reed in "Choice of Dialect," editorial, Language Learning, 1.4, 1948.

c. Language has system.

Edward Sapir in "Sound Patterns in Language," Language, 1.2 , 1925, p. 40 , says "... a complex psychology of association and pattern is implicit in the utterance of the simplest consonant or vowel." On all levels of language, not only pronunciation, system is manifested, with language forms falling into patterns. With this view of language, it is the system, instead of lists of unrelated items, that is presented in the classroom--the patterns of pronunciation, words, and syntax. The language teacher's subject can now be better defined, for the patterns of a language are limited.

d. Language is for communication.

Human beings communicate, that is, convey meaning to one another, through language. One implication of this aspect of language is that the vocabulary selection (selection of the lexical units) for a class will depend on the kind of communication situations the students will be in. Various word-lists have been compiled to help the teacher or textbook writer select a useful vocabulary. ${ }^{3}$ Some considerations of vocabulary selection are discussed by Robert Lado in "Patterns of Difficulty in Vocabulary," Language Learning 6.1-2, 1955, and by Michael West, "A Plateau Vocabulary for Speech," Language Learning, 7.1-2, 1956-1957. The vocabulary selection of Michigan's Intensive English Course textbooks is determined by the "areas of living" of the learners. ${ }^{4}$

2 Linguistic geographers have been determining language and dialect areas. For a description of the dialect areas of the eastern U, S. see: Kurath, Hans, with Marcus L. Hansen, Julia Bloch, and Bernard Bloch. Handbook of the Linguistic Geography of New England. Washington, D.C.: American Council of Learned Societies, 1939. See also: Kurath, Hans. A Word Geography of the Eastern United States. Ann Arbor: University of Michigan Press, 1949.

3 For a survey of English word-lists see: Fries, Charles C., and A. Aileen Traver [Kitchen]. English Word Lists: A Study of Their Adaptability for Instruction. Washington, D. C.: American Council on Education, 1940. For notes on more recent publications on vocabulary selection see: Lado, Robert. Annotated Bibliography for Teachers of English as a Foreign Language. (U.S. Department of Health, Education, and Welfare Bulletin 1955, No. 3) Washington, D.C.: U. S. Government Printing Office, 1955.

${ }^{4}$ Fries (1945 pp. 50-51. 
Another implication of this communicative feature of the nature of language comes in the presenting and practicing of the teaching points. The teacher sets up situations, or contexts, verbally and through the use of visual aids to teach a particular point. Thus, instead of emphasis on recitation of conjugations, declensions, terminology, and vocabulary lists, conversations and other utterances that communicate play a great role in the language classroom.

e. Language is made up of habits.

The patterns of a language are habits for speakers of the language. Practice is usually necessary to form language habits. In the words of the Canadian neurosurgeon, Wilder Penfield, ${ }^{5}$ language habits as developing in a child "are more than motor skills of tongue and lip; they are units of sound and units of thought established in a physical form within the brain. He uses these units over and over again while he is constructing the nerve cell basis of each new word, and he deposits these word patterns in special areas of the cerebral cortex." For second-language learning, Bloomfield (1914) recommended at least eight hours a week of constant drill in the first year or two. The ASTP called for many class hours and small classes. Pattern practice is an integral part of the Intensive Course in English of the English Language Institute, University of Michigan. Language laboratories ${ }^{6}$ have been established for additional practice opportunities, with tape recorders, phonographs, and other electronic devices. ${ }^{7}$ (John B. Carroll in The Study of Language, 1953, questions whether much drill is necessary for habit formation and says that psychologists must give the answer.)

f. There is a relation between a language and the culture in which it is used.

The extent of the relationship between language and culture, discussed in Language in Culture, Harry Hoijer, editor, 1954, remains in question. Statements made by Edward Sapir and

5 Penfield, Wilder. "The Human Brain and the Learning of Secondary Languages, "Radio Broadcast, mimeographed, New Delhi: February, 1957 .

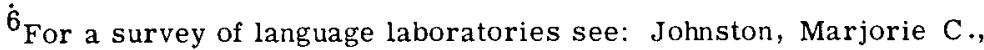
and Catharine C. Seerley. Foreign Language Laboratories in Schools and Colleges. (U. S. Department of Health, Education, and Welfare Bulletin 1959, No. 3) Washington, D.C.: U. S. Government Printing Office, 1958.

7The possibility of "teaching machines" to replace, not merely to supplement, the language teacher is being explored. 
Benjamin L. Whorf on this relationship are known as the SapirWhorf hypothesis. Sapir, in Selected Writings of Edward Sapir, D. G. Mandelbaum, editor, 1949, p. 162, said, "We see and hear and otherwise experience very largely as we do because the language habits of our community predispose certain choices of interpretation." Whorf, in Collected Papers on Metalinguis tics, 1952 , p. 36 , wrote of "fashions of speaking" within a language which largely make up the speaker's "'thought world'... the microcosm that each man carries about within himself, by which he measures and understands what he can of the macrocosm." It would seem, then, by knowing the patterns of a language we would learn something of the culture in which the language is used. But on the other hand, culture, the total situations in which a language is used, gives meaning to the utterances of a language (see 1.d above). The implication for the classroom is that the situation, the pattern of a culture, in which an utterance is made must be understood in order to understand a particular utterance. (We should not infer from this aspect of language that a language is limited to a particular culture. English, Spanish, French, and Arabic, for example, are being used in various cultures throughout the world.)

g. Languages change.

English today is different from the English at the time of Shakespeare and still more different from that of King Alfred's time. The fact that languages change, and the fact that language symbols are arbitrary (1.b), have led to movements to get rid of prescriptiveness in grammar books and to have descriptions instead. As evidence for these movements we have, for English, Fries' "What is Good English," 1928, reprinted in Teaching of English, 1949, and Facts about Current English Usage, Albert H. Marckwardt and Fred G. Walcott, 1938.

h. No two languages have the same set of patterns of pronunciation, words, and syntax.

What is true of one language system is not necessarily true of another; we cannot impose grammar rules from one language to another. That Latin has infinitives that are not split does not mean that English has or should have infinitives that are not split. Consideration of this uniqueness of each language system makes most word-for-word translations invalid, and suggests that translation is not a good teaching device. 
2. THE REALIZATION (ASSUMPTION) THAT PATTERNS OF ONE'S NATIVE LANGUAGE INTERFERE WITH LEARNING LATER THE PATTERNS OF ANOTHER LANGUAGE

Franz Boas in the introduction of the Handbook of American Indian Languages, Part I, 1911, p. 18, shows that in the interpretation of sounds of a second language "observers belonging to different nationalities readily perceive the sounds in accordance with the system of sounds with which they are familiar. Often it is not difficult to recognize the nationality of a recorder from the system selected by him for the rendering of sounds." Uriel Weinreich in Languages in Contact, 1953, pp. 18-19, lists under-differentiation of phonemes, over-differentiation of phonemes, reinterpretation of distinctions, and phone substitution as types of interference that may occur between sound systems of languages. This assumption of interference holds true for all levels of the language and all other areas of human behavior, as brought out by Kenneth $\mathrm{L}$. Pike in Language in Relation to a Unified Theory of the Structure of Human Behavior, 1954, p. 18, "Predictability of Difficulties in Learning to React Emically to an Alien Emic System," and as brought out by Robert Lado in Linguistics Across Cultures, 1957; the points of contrast between two language systems in pronunciation, words-including the cultural contexts in which they are used--and syntax, can be predicted as the points of difficulty for a speaker of one learning the other. The relevance of this assumption for the classroom is stated by Fries in "As We See It," Language Learning 1.1, 1948, p. 13; "The most efficient materials grow out of a scientific descriptive analysis of the language to be learned carefully compared with a parallel descriptive analysis of the native language of the learner. Only a comparison of this kind will reveal the fundamental trouble spots that demand special exercises and will separate the basically important features from a bewildering mass of linguistic details." Language tests, as well as daily teaching materials, as explained by Robert Lado in "Linguistic Science and Language Tests," Language Learning, 3.3-4, 1950, are affected by this assumption.

This realization of interference in later language learning, after the age of about 10 to 14 , makes us consider the advisability of beginning second language learning at an earlier age, when less interference seems to exist.

3. METHODS OF ANALYZING AND DESCRIBING LANGUAGES

The methods that modern linguistics uses to analyze and describe languages are described in the following publications: 
Language, Leonard Bloomfield, 1933

Outline of Linguistic Analysis, Bernard Bloch and George L. Trager, 1942

Outline Guide for the Practical Study of Foreign Languages, L. Bloomfield, 1942

The Intonation of American English, Kenneth L. Pike, 1945

Phonemics, K. L. Pike, 1947

Tone Languages, K. L. Pike, 1948

Morphology, Eugene A. Nida, 1949

Learning a Foreign Language, E. A. Nida, 1950

Methods in Structural Linguistics, Zellig S. Harris, 1951

Language, K. L. Pike, Part I, 1954; Part II, 1955; Part III, $1960^{8}$

An Introduction to Descriptive Linguistics, H. A. Gleason, Jr. , 1955

Syntactic Structures, Noam Chomsky, $1957^{9}$

Introduction to Linguistic Structures, Archibald A. Hill, 1958

A Course in Modern Linguistics, Charles F. Hockett, 1958

Although language teachers are not expected to make language analyses, a teacher equipped with some knowledge of how to go about analyzing a language is better prepared to spot students' difficulties in language learning-a necessity for good classes until materials such as Fries spoke of above are available for the various language classes.

\section{DESCRIPTIONS OF LANGUAGES}

The most active and continuing contribution of linguistics to the teaching of languages is the actual description of languages. Some descriptions have appeared in book form; most, in journals . In Lado's Linguistics Across Cultures there is a bibliography which gives the titles of some of the books and articles. Accompanying this paper is a list of descriptions of present-day languages that have appeared in the journals Language, Word, and Language Learning. Not only for the sake of teaching a

${ }^{8}$ As an outcome of these volumes, the use of the concept of the tagmeme in the language classroom is being discussed.

9 In connection with this book, transform grammars, grammars that generate sentences, or sequences of transformation rules, are being talked about with a view to their application in the language classroom. Of course conversion (transformation) exercises have been used in language classrooms for many years. 
language as a second language are these descriptions necessary, but also for teaching native speakers of a language about their own language.

Of course, most useful for the classroom teacher of the native language would be the actual textbooks based upon scientific descriptions, and in the case of second-language teaching textbooks based on scientific comparisons of these descriptions. An example of such a textbook of English for native speakers of English is Patterns of English, Paul Roberts, 1956, based on Fries', The Structure of English, 1952. Such textbooks of English for native speakers of Spanish are the books of An Intensive Course in English by the English Language Institute Staff of the University of Michigan. But until good textbooks are available for the various language teaching situations, the teacher is helped by these descriptions.

\section{TECHNIQUES FOR COMPARISON OF TWO LANGUAGES}

For second-language learning, as indicated above, descriptions of the languages alone are not enough; scientific comparisons of the native language of the learner with the language to be learned are essential. Robert Lado's Linguistics Across Cultures is a unique contribution for these comparisons. In this book he suggests the techniques for comparing two sound systems, two grammatical structures, two vocabulary systems, two writing systems, and two cultures. When comparisons are made following these techniques, then the difficult and easy parts for the language learner will be known and the teaching materials can be written in accordance with the findings. ${ }^{10}$

As in the case of other sciences, in the field of linguistics the practical "application," the classroom reflection, might antedate the scientific finding or statement; that is to say, language teachers may have taught in accordance with the five points above before the points were included within the scope of linguistic science. But more often, application has lagged behind scientific knowledge. It is the responsibility of a teacher to know the latest in his field and it is his privilege to go beyond it.

${ }^{10}$ The accompanying list of language descriptions includes language comparisons. 


\section{REFERENCES CITED}

Bloch, Bernard, and George L. Trager. OUTLINE OF LINGUISTIC ANALYSIS. Baltimore: Linguistic Society of America, 1942.

Bloomfield, Leonard. AN INTRODUCTION TO THE STUDY OF LANGUAGE. New York: Henry Holt and Co., 1914.

----. OUTLINE GUIDE FOR THE PRACTICAL STUDY OF FOREIGN LANGUAGES. Baltimore: Linguistic Society of America, 1942.

-.-.. LANGUAGE. New York: Henry Holt and Co., 1933.

Boas, Franz, editor. HANDBOOK OF AMERICAN INDIAN LANGUAGES, Part I; BUREAU OF AMERICAN ETHNOLOGY BULLETIN NO. 40. Washington, D. C.: U. S. Government Printing Office, 1911.

Carroll, John B. THE STUDY OF LANGUAGE: A SURVEY OF LINGUISTICS AND RELATED DISCIPLINES IN AMERICA. Cambridge, Mass.: Harvard University Press, 1953.

Chomsky, Noam. SYNTATIC STRUCTURES. The Hague, the Netherlands: Mouton and Co., 1957.

English Language Institute Staff, Robert Lado, Director; C. C. Fries, Consultant. AN INTENSIVE COURSE IN ENGLISH, 4 volumes. Ann Arbor: University of Michigan Press, revised editions, $1954-1958$.

Fries, Charles C., and A. Aileen Traver [Kitchin]. ENGLISH WORD LISTS: A STUDY OF THEIR ADAPTABILITY FOR INSTRUCTION. Washington, D. C.: American Council on Education, 1940.

Fries, Charles C., TEACHING AND LEARNING ENGLISH AS A FOREIGN LANGUAGE. Ann Arbor: University of Michigan Press, 1945.

-.... "As We See It," LANGUAGE LEARNING 1.1, 1948.

-.-. THE TEACHING OF ENGLISH: A SERIES OF ESSAYS ON WHAT IS GOOD ENGLISH?; TEACHING THE ENGLISH LANGUAGE, TEACHING LITERATURE. Ann Arbor: The George Wahr Publishing Co., 1949.

---.. THE STRUCTURE OF ENGLISH: AN INTRODUCTION TO THE CONSTRUCTION OF ENGLISH SENTENCES. New York: Harcourt, Brace and Co., 1952.

Gleason, H. A., Jr. AN INTRODUCTION TO DESCRIPTIVE LINGUISTICS. New York: Henry Holt and Co., 1955.

Harris, Zellig S. METHODS IN STRUCTURAL LINGUISTICS. Chicago: University of Chicago Press, 1951.

Hill, Archibald A. INTRODUCTION TO LINGUISTIC STRUC- 
TURES: FROM SOUND TO SENTENCE IN ENGLISH. New York: Harcourt, Brace and Co., 1958.

Hockett, Charles F. A COURSE IN MODERN LINGUISTICS. New York: The MacMillan Co., 1958.

Hoijer, Harry, editor. LANGUAGE IN CULTURE: CONFERENCE ON THE INTERRELATIONS OF LANGUAGE AND OTHER ASPECTS OF CULTURE. Chicago: The Univer sity of Chicago Press, 1954.

Johnston, Marjorie C., and Catharine C. Seerley. FOREIGN LANGUAGE LABORATORIES IN SCHOOLS AND COLLEGES. (U. S. Department of Health, Education, and Welfare Bulletin 1959, No. 3) Washington, D.C.: U. S. Government Printing Office; 1958.

Kurath, Hans, with Marcus L. Hansen, Julia Bloch, and Bernard Bloch. HANDBOOK OF THE LINGUISTIC GEOGRA PHY OF NEW ENGLAND. W shington, D. C.: American Council of Learned Societies, 1939.

Kurath, Hans. A WORD GEOGRAPHYOF THE EAST ERN UNITED STATES. Ann Arbor: University of Michigan Press, 1949. Lado, Robert, "Linguistic Science and Language Tests," LANGUAGE LEARNING, 3. 3-4, 1950.

-... ANNOTATED BIBLIOGRAPHY FOR TEACHERS OF ENG GLISH AS A FOREIGN LANGUAGE. U. S. Department of Health, Education, and Welfare Bulletin 1955, No. 3) Washington, D. C.: U. S. Government Printing Office, 1955. -.-. "Patterns of Difficulty in Vocabulary," LANGUAGE LEARNING, 6. 1-2, 1955.

---. LINGUISTICS ACROSS CULTURES: APPLIED LINGUISTICS FOR LANGUAGE TEACHERS. Ann Arbor: The Uni versity of Michigan Press: 1957.

Mandelbaum, David G., editor. SELECTED WRITINGS OF EDWARD SAPIR IN LANGUAGE, CULTURE AND PERSONALITY. Berkeley and Los Angeles: University of California Press, 1951.

Mackwardt, Albert H., and Fred G. Walcott. FACTS ABOUT CURRENT ENGLISH USAGE; ENGLISH MONOGRAPH NO. 7. A publication of the National Council of Teachers of English. New York: Appleton-Century Co., 1938.

Nida, Eugene A. MORPHOLOGY: THE DESCRIPTIVE ANALYSIS OF WORDS. Ann Arbor: The University of Michigan Press, revised edition, 1949.

---. LEARNING A FOREIGN LANGUAGE: A HANDBOOK FOR MISSIONARIES. New York: Committee on Missionary Personnel of the Foreign Missions Conference of North America, 1950 . 
Palmer, Harold E. THE ORAL METHOD OF TEACHING LAN GUAGES. Cambridge, England: W. Heffer and Sons, Ltd., 1923.

Penfield, Wilder. "The Human Brain and the Learning of Secondary Languages." Radio Broadcast, mimeographed. New Delhi: February, 1957.

Pike, Kenneth L. THE INTONATION OF AMERICAN ENGLISH. Ann Arbor: The University of Michigan Press, 1945.

-.-. PHONEMICS: A TECHNIQUE FOR REDUCING LANGUAGES TO WRITING. Ann Arbor: The University of Michigan Press, 1947.

---. TONE LANGUAGES: A TECHNIQUE FOR DETERMINING THE NUMBER AND TYPE OF PITCH CONTRASTS IN A LANGUAGE, WITH STUDIES IN TONEMIC SUBSTITUTION AND FUSION. Ann Arbor: The University of Michigan Press, 1948.

-.-. LANGUAGE: IN RELATION TO A UNIFIED THEORY OF THE STRUCTURE OF HUMAN BEHAVIOR. Glendale, Calif:: Summer Institute of Linguistics, Part I, 1954: Part II, 1955; Part III, 1960.

Reed, David W. "Choice of Dialect," editorial, LANGUAGE LEARNING, 1.4, 1948.

Roberts, Paul. PATTERNS OF ENGLISH. New York and Chicago: Harcourt, Brace and Co., 1956.

Sapir, Edward. "Sound Patterns in Language," LANGUAGE, $1.2,1925$.

Shannon, Claude L., and W. Weaver, THE MATHEMATICAL THEORY OF COMMUNICATION. Urbana: University of Illinois Press, 1949.

Sweet, Henry. THE PRACTICAL STUDY OF LANGUAGES: A GUIDE FOR TEACHERS AND LEARNERS. London: J. M. Dent and Co., 1899.

Sweet, Waldo E. "The Carrot on the Stick," editorial, LANGUAGE LEARNING 9. 1-2, 1959.

Weinreich, Uriel. LANGUAGES IN CONTACT: FINDINGS AND PROBLEMS. New York: Linguistic Circle of New York, 1953.

Welmers, William E. SPOKEN ENGLISH AS A FOREIGN LANGUAGE. Instructor's Manual, ACLS Program in English as a Foreign Language. Washington, D. C.: American Council of Learned Societies, 1953.

West, Michael. "A Plateau Vocabulary for Speech," LANGUAGE LEARNING, 7.1-2, 1956-1957. 
Whorf, Benjamin L. COLLECTED PAPERS ON METALINGUISTICS. Washington, D. C.: Department of State, Foreign Service Institute, 1952. 